\title{
Międzyresortowe komisje orzekające w sprawach o naruszenie dyscypliny finansów publicznych
}

Ustawą z dnia 19 sierpnia 2011 r. o zmianie ustawy o odpowiedzialności za naruszenie dyscypliny finansów publicznych oraz niektórych innych ustaw zwaną dalej ustawą zmieniającą - znowelizowano ustawę z dnia 17 grudnia 2004 r. o odpowiedzialności za naruszenie dyscypliny finansów publicznych (dalej: u.o.n.d.f.p. $)^{1}$.

W uzasadnieniu do projektu wyżej wskazanej ustawy zmieniającej podniesiono, że potrzeba nowelizacji u.o.n.d.f.p. wynikała $\mathrm{z}$ dokonania jej oceny pod kątem występujących w niej niedociągnięć. Uznano, że ówczesne rozwiązania wymagały rozszerzenia i umocnienia, aby w pełni zagwarantowane było należyte przeprowadzenie postępowania dyscyplinarnego, a w rezultacie ukaranie osób odpowiedzialnych za naruszenie dyscypliny finansów publicznych w sposób adekwatny do popełnionego naruszenia. Wskazano również, że powodem podjęcia ingerencji ustawodawczej było niewystarczające wypełnianie funkcji represyjnej postępowania w sprawach o naruszenie dyscypliny finansów publicznych. System odpowiedzialności wymagał także modyfikacji ze względu na zmiany w źródłach prawa finansowego oraz usunięcia wątpliwości interpretacyjnych². Dostrzeżono potrzebę poprawy skuteczności egzekwowania odpowiedzialności za naruszenie dyscypliny finansów publicznych, usprawnienia postępowania w sprawach

* Mgr Wojciech Bożek - Katedra Prawa Finansowego, Wydział Prawa i Administracji, Uniwersytet Szczeciński.

1 Ustawa z dnia 19 sierpnia 2011 r. o zmianie ustawy o odpowiedzialności za naruszenie dyscypliny finansów publicznych oraz niektórych innych ustaw (Dz. U. z 2011 r. Nr 240, poz. 1429); ustawa z dnia 17 grudnia 2004 r. o odpowiedzialności za naruszenie dyscypliny finansów publicznych (Dz. U. z 2005 r. Nr 14, poz. 114 ze zm.).

2 Uzasadnienie rządowego projektu ustawy o zmianie ustawy o odpowiedzialności za naruszenie dyscypliny finansów publicznych oraz niektórych innych ustaw (druk sejmowy nr 4465), http://orka.sejm.gov.pl/proc6.nsf/opisy/4465.htm, por. Założenia do projektu ustawy o zmianie ustawy o odpowiedzialności za naruszenie dyscypliny finansów publicznych oraz innych ustaw, przedłożone przez ministra finansów 1 marca 2011 r., www.premier.gov.pl oraz Projekt ustawy o zmianie ustawy o odpowiedzialności za naruszenie dyscypliny finansów publicznych oraz niektórych innych ustaw, przedłożony przez ministra finansów 19 lipca 2011 r., www.premier.gov.pl. 
o naruszenie dyscypliny, racjonalizacji kosztów dochodzenia odpowiedzialności, poszerzenia zakresu podmiotowego osób objętych odpowiedzialnością oraz zmodyfikowania wymiaru kar za naruszenia ${ }^{3}$.

Według stanu prawnego obowiązującego przed dokonaniem przedmiotowych zmian (art. 46 u.o.n.d.f.p.) komisjami orzekającymi w sprawach o naruszenie dyscypliny finansów publicznych były: wspólna komisja orzekająca, resortowe komisje orzekające przy ministrach kierujących działem lub działami administracji rządowej; komisja orzekająca przy Szefie Kancelarii Prezesa Rady Ministrów oraz regionalne komisje orzekające przy regionalnych izbach obrachunkowych.

Resortowe komisje orzekające orzekały w sprawach o naruszenie dyscypliny finansów publicznych w zakresie dotyczącym realizacji budżetu państwa w częściach, którymi dysponował minister kierujący działem lub działami administracji rządowej, z wyłączeniem środków przekazanych jednostkom samorządu terytorialnego, ich związkom i stowarzyszeniom oraz samorządowym jednostkom organizacyjnym, w tym samorządowym osobom prawnym. Nadto, do właściwości resortowych komisji orzekających należało również orzekanie w zakresie dotyczącym organów i jednostek podległych lub nadzorowanych przez ministra oraz jednostek im podległych lub przez nie nadzorowanych, a także innych jednostek otrzymujących środki publiczne przekazane z części budżetu państwa lub w zakresie innych środków publicznych, którymi dysponował minister lub wskazane wyżej organy i jednostki.

Zgodnie $\mathrm{z}$ art. 49 u.o.n.d.f.p. przed wejściem w życie ustawy zmieniającej, w sprawach o naruszenie dyscypliny finansów publicznych w zakresie dotyczącym osób pełniących funkcje wojewody, wicewojewody, dyrektora generalnego urzędu wojewódzkiego i głównego księgowego części budżetowej, której dysponentem był wojewoda oraz osób pełniących funkcje marszałka województwa, członka zarządu województwa i głównego księgowego budżetu województwa (skarbnika województwa) orzekała resortowa komisja orzekająca przy ministrze właściwym do spraw administracji publicznej.

W sporządzonym na podstawie art. 192 ust. 2 u.o.n.d.f.p. sprawozdaniu z działalności Głównej Komisji Orzekającej w Sprawach o Naruszenie Dyscypliny Finansów Publicznych oraz zbiorczym sprawozdaniu z działalności komisji orzekających pierwszej instancji w $2011 \mathrm{r}$ z dnia 12 marca 2012 r. wskazano, że z ogółu 232 spraw rozstrzygniętych w $2011 \mathrm{r}$. przez resortowe komisje orzekające najwięcej spraw rozstrzygnęły: Resortowa Komisja Orzekająca przy Ministrze Sprawiedliwości (77 spraw), Resortowa Komisja Orzekająca przy Ministrze Spraw Wewnętrznych i Administracji (32 sprawy) oraz Resortowa Komisja Orzekająca przy Ministrze Zdrowia i Resortowa Komisja Orzekająca przy Ministrze Obrony Narodowej (każda po 24 sprawy). Najmniej spraw rozstrzygniętych miały natomiast Resortowe Komisje Orzekające przy: Ministrze Edukacji Narodowej

${ }^{3}$ Rządowy projekt ustawy o zmianie ustawy o odpowiedzialności za naruszenie dyscypliny finansów publicznych oraz niektórych innych ustaw, http://orka.sejm.gov.pl/proc6.nsf/opisy/4465.htm. 
(1 sprawa), Ministrze Gospodarki (1 sprawa), Ministrze Rozwoju Regionalnego (2 sprawy), Ministrze Spraw Zagranicznych (2 sprawy), Ministrze Środowiska (2 sprawy). W 2011 r. ani razu nie orzekała komisja przy Ministrze Sportu i Turystyki. Nadmienić należy, że w dniu 17 listopada 2011 r. wygasły kadencje Resortowej Komisji Orzekającej przy Ministrze Infrastruktury oraz przy Ministrze Spraw Wewnętrznych i Administracji, co spowodowane zostało zniesieniem organów, przy których działały te komisje ${ }^{4}$.

Na początku $2011 \mathrm{r}$. w komisjach orzekających pierwszej instancji oczekiwały na rozstrzygnięcie wnioski o ukaranie dotyczące 480 obwinionych (w 2010 r. 590 , zaś w 2009 r. - 448), w tym w resortowych komisjach orzekających - 80 obwinionych, zaś w regionalnych komisjach orzekających - 400 obwinionych. Nadto, w 2011 r. do komisji orzekających w pierwszej instancji wpłynęły wnioski o ukaranie 1676 obwinionych (201 obwinionych - do resortowych komisji orzekających, pozostałe - do regionalnych komisji orzekających), co stanowi wzrost ilościowy o 352 obwinionych w stosunku do stanu z $2010 \mathrm{r}$.

Uwzględniając z kolei fakt, że $\mathrm{w}$ ww. okresie do ponownego rozpoznania zwrócono sprawy dotyczące 35 obwinionych (do resortowych komisji orzekających -14 obwinionych, natomiast do regionalnych komisji orzekających sprawy dotyczące 21 obwinionych), stwierdzić należy, iż w komisjach orzekających pierwszej instancji pozostawały łącznie do rozpoznania w 2011 r. sprawy dotyczące 2191 obwinionych, w tym 296 obwinionych w resortowych komisjach orzekających, natomiast co do pozostałych obwinionych - w regionalnych komisjach orzekających ${ }^{5}$.

Celem zobrazowania zakresu spraw rozpatrywanych w tym samym roku przez regionalne komisje orzekające wspomnieć należy, że z ogółu 1437 spraw rozstrzyganych przez nie w ciągu 2011 r.: Regionalna Komisja Orzekająca przy RIO w Krakowie rozstrzygnęła 215 spraw, w Poznaniu - 213 spraw, w Katowicach - 141 spraw, najmniej natomiast we Wrocławiu - 20 spraw. Wskazuje to na istnienie znacznych dysproporcji w obciążeniu pracą poszczególnych komisji orzekających, ale nadto, w podziale na resortowe i regionalne komisje orzekające, co zostało zauważone przez ustawodawcę i stanowiło tym samym asumpt do dokonania zmian organizacyjnych w powyższym zakresie ${ }^{6}$.

${ }^{4}$ Sprawozdanie z działalności Głównej Komisji Orzekającej w Sprawach o Naruszenie Dyscypliny Finansów Publicznych oraz zbiorcze sprawozdanie z działalności komisji orzekających I instancji w 2011 r. z dnia 12 marca 2012 r., s. 18, www.mf.gov.pl, por. Sprawozdanie z działalności Głównej Komisji Orzekającej w Sprawach o Naruszenie Dyscypliny Finansów Publicznych oraz zbiorcze sprawozdanie z działalności komisji orzekających I instancji w 2009 r. z dnia 11 marca 2010 r., www.mf.gov.pl, s. 11-18, por. Sprawozdanie z działalności Głównej Komisji Orzekającej w Sprawach o Naruszenie Dyscypliny Finansów Publicznych oraz zbiorcze sprawozdanie z działalności komisji orzekających I instancji w 2010 r. z dnia 11 marca 2011 r., www.mf.gov.pl, s. 12-21.

5 Sprawozdanie z działalności Głównej Komisji Orzekającej..., s. 15-18.

${ }^{6}$ Ibidem, s. 17-18. 
Warto zauważyć, że komisje orzekające pierwszej instancji wydały w $2011 \mathrm{r}$. rozstrzygnięcia wobec 1669 obwinionych, co wskazuje na tendencję wzrostową rozstrzyganych spraw, bowiem w roku 2010 r. rozstrzygnięto 1458 spraw, zaś w 2009 r. - 1318 spraw. Ponadto, na koniec 2011 r. do rozstrzygnięcia pozostały wnioski o ukaranie 478 obwinionych, w tym w regionalnych komisjach orzekających - wobec 414 obwinionych, natomiast w resortowych komisjach orzekających - wobec zaledwie 64 obwinionych. Wyjaśnić jednak należy, iż różnica pomiędzy liczbą złożonych wniosków a rozpoznawanych spraw wynika z łącznego rozpoznania spraw pozostających w ścisłym związku?

Na podstawie danych opublikowanych przez Ministerstwo Finansów można stwierdzić, iż komisje orzekające pierwszej instancji w 2011 r. wydały ogółem orzeczenia wobec 1320 obwinionych. Porównując zaś stan istniejący w latach poprzednich zauważyć można, iż liczba wydanych orzeczeń w zakresie odpowiedzialności za naruszenie dyscypliny finansów publicznych wzrastała, tj. z 1062 wydanych orzeczeń w 2009 r. do 1195 w 2010 r. oraz, jak to już wyżej wskazano, do 1320 wydanych orzeczeń w 2011 r. Przy czym, uniewinniono 330 osób, tj. 24,8\% wszystkich obwinionych, wobec których wydano orzeczenia w $2011 \mathrm{r}$., w samych zaś resortowych komisjach orzekających 83 osoby, co stanowiło 25,2\% wszystkich uniewinnionych. W tym samym okresie odpowiedzialnymi za naruszenie dyscypliny finansów publicznych uznano 990 osób (75\% wszystkich obwinionych, wobec których wydano orzeczenia), z czego resortowe komisje orzekające orzekały o uznaniu odpowiedzialności za naruszenie dyscypliny finansów publicznych wobec 95 osób, co stanowiło 9,5\% obwinionych, którym przypisano odpowiedzialność 8 .

W 2011 r. w resortowych komisjach orzekających umorzono postępowanie wobec 54 osób (z ogólnej liczby 349 umorzonych postępowań), przy czym wnioski złożone przez rzecznika najczęściej nie kończyły się przypisaniem odpowiedzialności w Resortowej Komisji Orzekającej przy Ministrze Pracy i Polityki Społecznej (10 spraw), Resortowej Komisji Orzekającej przy Ministrze Kultury i Dziedzictwa Narodowego (9 spraw) oraz Resortowej Komisji Orzekającej przy Ministrze Infrastruktury (7 spraw) ${ }^{9}$.

Z opublikowanego przez Ministerstwo Finansów sprawozdania z działalności Głównej Komisji Orzekającej w Sprawach o Naruszenie Dyscypliny Finansów Publicznych oraz zbiorczego sprawozdania z działalności komisji orzekających pierwszej instancji w 2011 r. z dnia 12 marca 2012 r. wynika, iż spośród 990 osób, które zostały uznane za odpowiedzialne za naruszenie dyscypliny finansów publicznych w 2011 r. (w 2010 r. - 829, w 2009 r. - 790), resortowe komisje orzekające przypisały odpowiedzialność 95 obwinionym (regionalne komisje orzekające - 895 obwinionym), przy czym ukarano łącznie 421 osób (42,5\%), w tym

\footnotetext{
${ }^{7}$ Ibidem, s. 17

8 Ibidem, s. 19.

9 Ibidem, s. 20.
} 
48 osób w resortowych komisjach orzekających (373 w regionalnych komisjach orzekających). Wobec 47 osób resortowe komisje orzekające odstąpiły od wymierzenia kary, zaś regionalne komisje orzekające - wobec 522 osób, co łącznie stanowiło $57,5 \%$ ogólnej liczny uznanych za odpowiedzialnych za naruszenie dyscypliny finansów publicznych. Okolicznościami łagodzącymi, decydującymi najczęściej o odstąpieniu od wymierzenia kary, były przede wszystkim: uprzednia niekaralność obwinionego, wyróżnianie się obwinionego przed popełnieniem naruszenia, wzorowe wypełnianie obowiązków zawodowych, niska szkodliwość popełnionego naruszenia dla finansów publicznych czy też podjęcie działań zmierzających do wyeliminowania uchybien ${ }^{10}$.

Obecne brzmienie art. 46 u.o.n.d.f.p. wskazuje, iż komisjami orzekającymi w sprawach o naruszenie dyscypliny finansów publicznych są, niezmiennie, wspólna komisja orzekająca, komisja orzekająca przy Szefie Kancelarii Prezesa Rady Ministrów oraz regionalne komisje orzekające przy regionalnych izbach obrachunkowych. Z kolei w miejsce dotychczasowych resortowych komisji orzekających przy ministrach kierujących działem lub działami administracji rządowej utworzono międzyresortowe komisje orzekające przy ministrze właściwym do spraw finansów publicznych, ministrze właściwym do spraw administracji publicznej oraz ministrze sprawiedliwości.

W literaturze przedmiotu wielokrotnie podnoszono konieczność zmian w powyższym zakresie, podając $\mathrm{w}$ wątpliwość zasadność funkcjonowania komisji orzekających przy każdym ministrze, szczególnie, że obok komisji resortowych, w których rozpatrywana była duża liczba spraw (porównywalna z niektórymi komisjami regionalnymi), występowała również znaczna liczba komisji resortowych, które były powołane w składzie ustawowym, obejmującym - zgodnie $\mathrm{z}$ art. 43 ust. 1 u.o.n.d.f.p. - przewodniczącego, jednego lub dwóch jego zastępców i od 5 do 21 członków komisji. Komisje te rozpatrywały po jednej lub dwie sprawy rocznie, a zdarzały się sytuacje, kiedy poszczególne komisje nie rozpatrywały żadnych spraw. Tym samym wprowadzone zmiany urzeczywistniły propozycje ustawowego zmniejszenia liczby komisji resortowych, przy określeniu ich właściwości dla kilku lub kilkunastu działów administracji rządowej, bowiem również do rzeczników dyscypliny finansów publicznych w tych resortach wpływały rocznie pojedyncze zawiadomienia o ujawnionych okolicznościach, wskazujących na naruszenie dyscypliny finansów publicznych ${ }^{11}$.

Analiza funkcjonowania komisji orzekających pierwszej instancji wskazuje, że ograniczenie liczby komisji resortowych było w pełni uzasadnione, bowiem liczbę resortowych komisji orzekających uzależniano od liczby resortów, nie zaś

${ }^{10}$ Ibidem, s. 19-22.

${ }^{11}$ Por. K. Borowska, A. Kościńska-Paszkowska, Odpowiedzialność za naruszenie dyscypliny finansów publicznych. Komentarz, Warszawa 2010, s. 464, por. M. Malinowski, „Represyjna” nowelizacja przepisów o dyscyplinie finansów publicznych z dnia 3 lutego 2011 r., www.lex.pl, www.mofnet.gov.pl. 
od faktycznego obciążenia pracą komisji, wynikającego z liczby rozpatrywanych spraw. Wobec powyższego, w miejsce siedemnastu resortowych komisji orzekających przy ministrach kierujących działem lub działami administracji rządowej powołano trzy międzyresortowe komisje orzekające. Nadal funkcjonowały natomiast wszystkie pozostałe komisje orzekające pierwszej instancji wskazane w art. 46 u.o.n.d.f.p., tj. przy Szefie Kancelarii Prezydenta Rzeczypospolitej Polskiej, Szefie Kancelarii Prezesa Rady Ministrów oraz szesnaście komisji przy regionalnych izbach obrachunkowych ${ }^{12}$.

Ograniczenie liczby komisji orzekających właściwych w sprawach, w których dotychczas orzekały resortowe komisje orzekające znajdowało również swoje uzasadnienie $\mathrm{w}$ dużym zróżnicowaniu liczby spraw rozpoznawanych przez te komisje. Przy czym należy podkreślić, iż w uzasadnieniu ustawy zmieniającej opierano się na analizie danych statystycznych obejmujących liczbę spraw rozpoznanych przez te komisje w latach 2006-2009 (w uwzględnionym okresie resortowe komisje orzekające średnio rozpoznawały łącznie 261 spraw w ciągu roku). Mając zaś na uwadze fakt, że począwszy od $2006 \mathrm{r}$. liczba spraw rozpoznawanych przez resortowe komisje orzekające zmniejszała się (od 385 w 2006 r. do 194 w 2009 r.), istnienie komisji orzekających w ówczesnym kształcie nie znajdowało uzasadnienia także ze względu na koszty ponoszone na ich działalność, w szczególności na ryczałtowe wynagrodzenia miesięczne ${ }^{13}$.

Konkludując, aktualnie utworzono trzy komisje o zwiększonej liczbie członków, przy czym przesłanką decydującą o powołaniu komisji przy ministrze właściwym ds. finansów publicznych był fakt, że minister ten jest właściwy w zakresie działu finanse publiczne. $\mathrm{Z}$ kolei powołanie dwóch pozostałych komisji międzyresortowych - przy ministrze właściwym do spraw administracji publicznej i ministrze sprawiedliwości - miało na celu zapobieżenie problemom natury organizacyjnej (związanym z częstotliwością pracy komisji oraz zapewnieniem jej właściwych warunków), które mogłyby się pojawić, gdyby funkcjonowała tylko jedna komisja. Co więcej, utworzenie trzech komisji orzekających, które orzekają w znacznej liczbie spraw, oprócz oszczędności finansowych ma przyczynić się także do podniesienia poziomu merytorycznego orzecznictwa ${ }^{14}$.

Wprowadzenie międzyresortowych komisji orzekających skutkowało koniecznością uregulowania ich właściwości. $\mathrm{W}$ art. 48-49b u.o.n.d.f.p. określono właściwość tych komisji, co do zasady, w odniesieniu do działów administracji rządowej (części budżetu państwa odpowiadających tym działom). Zachowano przy tym szczególną właściwość międzyresortowej komisji orzekającej przy ministrze właściwym do spraw administracji publicznej, tj. w sprawach osób pełniących funkcje marszałka województwa, członka zarządu województwa i skarbnika

\footnotetext{
${ }_{12}$ Por. Uzasadnienie rządowego projektu...

13 Ibidem.

${ }^{14}$ Ibidem.
} 
województwa oraz wojewody, wicewojewody, dyrektora generalnego urzędu wojewódzkiego i głównego księgowego części budżetowej, której dysponentem jest wojewoda ${ }^{15}$. Natomiast w związku z możliwością wystąpienia sytuacji, w której nie będzie możliwe ustalenie właściwości na podstawie przepisów określających właściwość komisji międzyresortowych - ustawodawca podaje jako przykład sytuację, gdy utworzono nową część budżetową, którą nie dysponuje minister ustalono, że właściwa będzie międzyresortowa komisja orzekająca przy ministrze właściwym do spraw finansów publicznych ${ }^{16}$.

Zgodnie $\mathrm{z}$ aktualnie obowiązującym porządkiem prawnym międzyresortowa komisja orzekająca przy ministrze właściwym do spraw finansów publicznych orzeka $\mathrm{w}$ sprawach o naruszenie dyscypliny finansów publicznych w zakresie dotyczącym realizacji budżetu państwa w częściach ustalonych dla takich działów administracji rządowej, jak: budżet, finanse publiczne, instytucje finansowe, członkostwo Rzeczypospolitej Polskiej w Unii Europejskiej, kultura i ochrona dziedzictwa narodowego, kultura fizyczna, nauka, oświata i wychowanie, rolnictwo, rozwój wsi, rynki rolne, rybołówstwo, szkolnictwo wyższe, turystyka, sprawy zagraniczne, zdrowie. Nadto, międzyresortowa komisja orzekająca przy ministrze właściwym do spraw finansów publicznych orzeka w sprawach o naruszenie dyscypliny finansów publicznych w zakresie realizacji budżetu państwa w częściach innych niż ustalone dla działów administracji rządowej, którymi dysponują ministrowie kierujący działami, o których mowa wyżej. Przy czym, z powyższego zakresu orzekania wyłączono środki przekazane jednostkom samorządu terytorialnego, ich związkom i stowarzyszeniom z wyłączeniem osób pełniących funkcje marszałka województwa, członka zarządu województwa i głównego księgowego budżetu województwa (skarbnika województwa) oraz środki przekazane samorządowym jednostkom organizacyjnym, w tym samorządowym osobom prawnym ${ }^{17}$.

Do właściwości ww. międzyresortowej komisji orzekającej należy również orzekanie w zakresie dotyczącym organów i jednostek podległych ministrom kierującym wskazanymi wyżej działami lub nadzorowanych przez tych ministrów oraz jednostek im podległych lub przez nie nadzorowanych, a także w zakresie innych podmiotów otrzymujących środki publiczne przekazane ze wskazanych w ustawie części budżetu państwa lub z innych środków publicznych, którymi dysponują ministrowie kierujący poszczególnymi działami lub też organy i jednostki podległe temu ministrowi.

Z kolei, zgodnie z art. 49 u.o.n.d.f.p., międzyresortowa komisja orzekająca przy ministrze właściwym do spraw administracji publicznej orzeka w sprawach

15 Ibidem.

16 Ustawa z dnia 17 grudnia 2004 r. o odpowiedzialności..., art. 49b oraz por. Uzasadnienie rządowego projektu...

17 Ustawa z dnia 17 grudnia 2004 r. o odpowiedzialności..., art. 48. 
o naruszenie dyscypliny finansów publicznych w zakresie dotyczącym realizacji budżetu państwa w częściach ustalonych dla takich działów administracji rządowej, jak administracja publiczna, budownictwo, gospodarka przestrzenna i mieszkaniowa, gospodarka morska, gospodarka wodna, informatyzacja, łączność, obrona narodowa, praca, rozwój regionalny, Skarb Państwa, transport, środowisko, rodzina, sprawy wewnętrzne, wyznania religijne oraz mniejszości narodowe i etniczne, zabezpieczenie społeczne, $\mathrm{z}$ wyłączeniem środków przekazanych jednostkom samorządu terytorialnego, ich związkom i stowarzyszeniom. Komisja ta orzeka również w zakresie realizacji budżetu państwa w częściach innych niż ustalone dla działów administracji rządowej, którymi dysponują ministrowie kierujący działami wymienionymi powyżej. Przy czym wyłączono z powyższego zakresu środki przekazane jednostkom samorządu terytorialnego, ich związkom i stowarzyszeniom oraz samorządowym jednostkom organizacyjnym, w tym samorządowym osobom prawnym ${ }^{18}$.

Międzyresortowa komisja orzekająca przy ministrze właściwym do spraw administracji publicznej orzeka również w sprawach o naruszenie dyscypliny finansów publicznych w zakresie dotyczącym osób pełniących funkcje marszałka województwa, członka zarządu województwa i głównego księgowego budżetu województwa (skarbnika województwa), osób pełniących funkcje wojewody, wicewojewody, dyrektora generalnego urzędu wojewódzkiego i głównego księgowego części budżetowej, której dysponentem jest wojewoda, dalej zaś, organów i jednostek podległych ministrom kierującym działami wskazanymi powyżej lub nadzorowanych przez tych ministrów oraz jednostek im podległych lub przez nie nadzorowanych. Komisja ta jest również właściwa w sprawach dotyczących innych podmiotów otrzymujących środki publiczne przekazane z części budżetu państwa lub z innych środków publicznych, którymi dysponują ministrowie kierujący właściwymi działami lub organy i jednostki im podległe ${ }^{19}$.

Międzyresortowa komisja orzekająca przy Ministrze Sprawiedliwości orzeka $\mathrm{w}$ sprawach o naruszenie dyscypliny finansów publicznych w zakresie dotyczącym realizacji budżetu państwa w części ustalonej dla działu administracji rządowej sprawiedliwość, w częściach innych niż ustalona dla działu administracji rządowej sprawiedliwość, którymi dysponuje Minister Sprawiedliwości, w części, którą dysponuje Prokurator Generalny z wyłączeniem środków przekazanych jednostkom samorządu terytorialnego, ich związkom i stowarzyszeniom (z wyłączeniem osób pełniących funkcje marszałka województwa, członka zarządu województwa i głównego księgowego budżetu województwa - skarbnika województwa) oraz samorządowym jednostkom organizacyjnym, w tym samorządowym osobom prawnym. Nadto, międzyresortowa komisja orzekająca przy Ministrze Sprawiedliwości orzeka w sprawach o naruszenie dyscypliny finansów publicznych w zakresie

\footnotetext{
18 Ibidem, art. 49.

19 Ibidem.
} 
dotyczącym organów i jednostek podległych Ministrowi Sprawiedliwości albo Prokuratorowi Generalnemu lub nadzorowanych przez Ministra Sprawiedliwości albo Prokuratora Generalnego, a także jednostek podległych tym organom lub jednostkom lub nadzorowanych przez te organy lub jednostki oraz innych podmiotów otrzymujących środki publiczne przekazane z wyżej wskazanych części budżetu państwa, lub z innych środków publicznych, którymi dysponują Minister Sprawiedliwości, Prokurator Generalny lub organy i jednostki im podległe lub nadzorowane oraz podległe tym jednostkom lub przez nie nadzorowane ${ }^{20}$.

Analizowane zmiany, związane $\mathrm{z}$ wprowadzeniem do kanonu komisji orzekających w sprawach o naruszenie dyscypliny finansów publicznych międzyresortowych komisji orzekających, wiązały się z koniecznością modyfikacji trybu powoływania przewodniczących i zastępców przewodniczących tych komisji oraz ich członków.

Zgodnie $\mathrm{z}$ art. 53 ust. 1 oraz ust. 3 u.o.n.d.f.p., przewodniczących międzyresortowych komisji orzekających i ich zastępców powołuje i odwołuje, na wniosek ministra właściwego do spraw finansów publicznych, niezmiennie Prezes Rady Ministrów. Przy czym są powoływani spośród kandydatów zgłoszonych do międzyresortowych komisji orzekających przez ministra, przy którym działa dana komisja. Wcześniejsze uregulowania w tym zakresie zakładały, że przewodniczącego oraz zastępcę (zastępców) resortowej komisji orzekającej przy ministrze kierującym działem lub działami administracji rządowej powoływał ten właśnie minister $^{21}$.

Przewodniczący międzyresortowej komisji orzekającej występuje dalej do ministrów kierujących działami administracji rządowej objętymi właściwością danej komisji, a w przypadku międzyresortowej komisji orzekającej przy ministrze sprawiedliwości - również do Prokuratora Generalnego, o przedstawienie kandydatów na członków tej komisji. Kandydatów przedstawia się w terminie 14 dni od dnia wystąpienia $^{22}$. Przy czym, członkami międzyresortowej komisji orzekającej nie mogą być kierownik i zastępca kierownika komórki bezpośrednio odpowiedzialnej za wykonanie budżetu państwa w zakresie części objętej właściwością danej komisji lub planu finansowego jednostki budżetowej - urzędu obsługującego ministra będącego dysponentem tej części, a w przypadku międzyresortowej komisji orzekającej przy Ministrze Sprawiedliwości - również Prokuratora Generalnego. Dostosowano w ten sposób regulację zapewniającą bezstronność komisji23.

Konsekwencją powołania międzyresortowych komisji orzekających jest także zmiana art. 70 ust. 1 u.o.n.d.f.p. regulującego koszty funkcjonowania komisji orzekających pierwszej instancji. W myśl zawartych w nim uregulowań obowią-

\footnotetext{
20 Ibidem, art. 49a

${ }^{21}$ Ibidem, art. 53.

22 Ibidem.

23 Ibidem, art. 55.
} 
zek zapewnienia siedziby, obsługi prawnej i administracyjno-technicznej oraz ponoszenia wydatków związanych z funkcjonowaniem komisji międzyresortowych i powołanych przy nich rzeczników został nałożony na ministrów, przy których utworzono komisje międzyresortowe, tj. ministra właściwego do spraw finansów publicznych, ministra właściwego do spraw administracji publicznej i ministra sprawiedliwości, co pozostawało w zgodzie z dotychczasową zasadą obciążenia tymi obowiązkami organu, przy którym działa komisja orzekająca i rzecznik dyscypliny ${ }^{24}$.

Z uwagi na to, iż właściwość rzeczników jest związana z właściwością komisji orzekającej, odpowiedniego dostosowania wymagały również przepisy dotyczące trybu powoływania rzeczników dyscypliny i ich zastępców oraz konieczne było sformułowanie przepisów dostosowujących działalność rzeczników dyscypliny finansów publicznych.

Dlatego też w art. 15 ustawy zmieniającej wskazano, że rzecznicy dyscypliny finansów publicznych i ich zastępcy, powołani przy resortowych komisjach orzekających przy ministrach kierujących działem lub działami administracji rządowej, do dnia odwołania pełnili swoją funkcję odpowiednio przy komisji, przy której zostali powołani oraz przy międzyresortowej komisji orzekającej, która przejęła sprawy prowadzone przez tę komisję. $Z$ kolei z dniem powołania przy właściwej międzyresortowej komisji orzekającej odpowiednio rzecznika dyscypliny finansów publicznych i jego zastępców, nie później jednak niż w terminie 2 miesięcy od dnia wejścia w życie ustawy zmieniającej, Główny Rzecznik Dyscypliny Finansów Publicznych zobowiązany był do odwołania dotychczasowych rzeczników i ich zastępców. Zastrzeżono jednak, że ww. rzecznicy i ich zastępcy, nie później niż w terminie miesiąca od dnia odwołania, powinni przekazać właściwym rzecznikom dyscypliny finansów publicznych przy międzyresortowych komisjach orzekających zawiadomienia o naruszeniu dyscypliny finansów publicznych w sprawach niezakończonych wydaniem postanowienia o wszczęciu postępowania wyjaśniającego albo o odmowie wszczęcia tego postępowania, akta spraw, w których toczyło się postępowanie w sprawie o naruszenie dyscypliny finansów publicznych oraz akta spraw, w których nie rozpoznano złożonego zażalenia na postanowienie o umorzeniu postępowania wyjaśniającego albo o odmowie wszczęcia tego postępowania oraz w których nie upłynął termin na jego złożenie ${ }^{25}$.

Rzecznicy dyscypliny finansów publicznych i ich zastępcy, powołani przy resortowych komisjach orzekających przy ministrach kierujących działem lub działami administracji rządowej, nie później niż w terminie miesiąca od dnia odwołania zostali zobowiązani również do złożenia sprawozdania dotyczącego ich działalności za okres sprawozdawczy lub część tego okresu przypadającą przed

\footnotetext{
24 Ibidem, art. 70.

25 Ustawa z dnia 19 sierpnia 2011 r. o zmianie ustawy o odpowiedzialności..., art. 15.
} 
dniem ich odwołania, zaś rzecznicy dyscypliny finansów publicznych powołani przy międzyresortowych komisjach orzekających przejęli sprawy prowadzone przez rzeczników i ich zastępców stosownie do właściwości komisji, przy której zostali powołani. W przypadku, gdyby międzyresortowa komisja orzekająca została powołana przed dniem odwołania rzecznika dyscypliny lub jego zastępcy przy komisji resortowej, rzecznicy ci mieli być właściwi w sprawach prowadzonych przez właściwą komisję międzyresortową, która przejęła sprawy z komisji resortowej, przy której byli powołani ${ }^{26}$.

Aktualnie kandydatów na rzeczników dyscypliny i ich zastępców zgłaszają właściwi ministrowie kierujący działami administracji rządowej objętymi właściwością międzyresortowych komisji orzekających, zaś w przypadku międzyresortowej komisji orzekającej przy Ministrze Sprawiedliwości - również Prokurator Generalny. W uzasadnieniu do ustawy zmieniającej wskazano, że liczbę zastępców rzecznika dyscypliny Główny Rzecznik będzie dostosowywał do potrzeb wynikających z liczby rozpatrywanych spraw, dlatego też Główny Rzecznik nie ma obowiązku kierowania wniosku o zgłoszenie kandydatów do wszystkich ministrów, lecz jedynie do niektórych z nich ${ }^{27}$.

Rzecznik dyscypliny i jego zastępcy są właściwi w sprawach rozpatrywanych przez komisję orzekającą, przy której zostali powołani. Wszelkie zaś spory o właściwość rozstrzyga Główny Rzecznik. Jednocześnie w art. 64 u.o.n.d.f.p. wskazano, że o powołaniu lub odwołaniu rzecznika dyscypliny lub jego zastępcy powiadamia się odpowiednio właściwego ministra, przy którym działa międzyresortowa komisja orzekająca, a w przypadku rzecznika dyscypliny lub jego zastępcy powołanego przy międzyresortowej komisji orzekającej - również ministra kierującego działem administracji rządowej lub Prokuratora Generalnego, który przedstawił jego kandydaturę 28 .

W konsekwencji zmniejszenia liczby komisji rozpatrujących sprawy należące dotychczas do właściwości komisji resortowych zrezygnowano również z możliwości powoływania rzeczników właściwych w sprawach rozpoznawanych przez więcej niż jedną komisję.

Zgodnie $\mathrm{z}$ art. 13 ustawy zmieniającej międzyresortowe komisje orzekające przy ministrze właściwym do spraw finansów publicznych, przy ministrze właściwym do spraw administracji publicznej i przy ministrze sprawiedliwości przejęły, stosownie do ich właściwości, sprawy prowadzone przez resortowe komisje orzekające przy ministrach kierujących działem lub działami administracji rządowej. Kadencja resortowej komisji orzekającej przy ministrze kierującym działem lub działami administracji rządowej wygasała $\mathrm{z}$ dniem powołania przewodniczą-

${ }^{26}$ Ibidem, art. 16 oraz por. Uzasadnienie rządowego projektu...

${ }^{27}$ Ustawa z dnia 17 grudnia 2004 r. o odpowiedzialności..., art. 62 oraz por. Uzasadnienie rządowego projektu...

${ }^{28}$ Ustawa z dnia 17 grudnia 2004 r. o odpowiedzialności..., art. 62a, 64; por. Uzasadnienie rządowego projektu... 
cego międzyresortowej komisji orzekającej, która przejęła sprawy prowadzone przez tę komisję (nie później jednak niż z upływem miesiąca od dnia wejścia w życie ustawy zmieniającej, w ocenie ustawodawcy był to czas wystarczający na powołanie na podstawie przepisów u.o.n.d.f.p. przewodniczących nowych komisji). Zastrzeżono jednak, że przewodniczący resortowych komisji orzekających przy ministrach kierujących działem lub działami administracji rządowej mieli przekazać przewodniczącemu właściwej międzyresortowej komisji orzekającej, niezwłocznie po jego powołaniu, akta spraw, w których toczyło się postępowanie o naruszenie dyscypliny finansów publicznych, a nadto, w których prawomocne orzeczenia nie zostały wykonane oraz ukaranie nie uległo zatarciu ${ }^{29}$.

Z kolei sprawozdania dotyczące wniosków o ukaranie wniesionych do resortowych komisji orzekających przy ministrach kierujących działem lub działami administracji rządowej za okres sprawozdawczy lub część tego okresu przypadającą przed dniem wygaśnięcia kadencji tych komisji składali przewodniczący tych komisji, nie później niż w terminie miesiąca od dnia wygaśnięcia kadencji tych komisji. Właściwa międzyresortowa komisja orzekająca prowadziła zatem przejęte sprawy w dalszym ciągu, przy czym rozprawy odroczone należało prowadzić $\mathrm{w}$ nowym terminie $\mathrm{w}$ dalszym ciągu, a jeżeli skład orzekający został zmieniony, należało ujawnić dowody przeprowadzone poprzednio ${ }^{30}$.

Wprowadzenie w art. 17 ustawy zmieniającej upoważnienia dla Prezesa Rady Ministrów do dokonania przeniesienia między częściami budżetu państwa wydatków związanych z funkcjonowaniem resortowych komisji orzekających i rzeczników dyscypliny (w zakresie zapewnienia siedziby, obsługi prawnej i administracyjno-technicznej komisji orzekającej oraz rzecznika i jego zastępcy właściwych w sprawach tej komisji, wydatki związane $\mathrm{z}$ ich funkcjonowaniem, wypłatą wynagrodzeń i szkoleniem oraz zwrotem świadkom kosztów przejazdu, finansowanych $\mathrm{z}$ budżetu państwa) było podyktowane nową organizacją komisji orzekających, tj. powołaniem komisji międzyresortowych. Funkcjonowanie międzyresortowych komisji orzekających, z uwagi na ich rozszerzoną właściwość i znaczną liczbę spraw do nich wpływających, wiązało się bowiem z koniecznością zapewnienia dodatkowej obsługi organizacyjnej i administracyjno-prawnej tym komisjom i właściwym rzecznikom dyscypliny finansów publicznych. Roczne wydatki związane z zatrudnieniem dodatkowych 10 osób, wykonujących przedmiotową obsługę, według przyjętych założeń miały wynosić ok. 580 tys. zł (w tym na wynagrodzenia - ok. 540 tys. zł, na pokrycie pozaosobowych kosztów utrzymania stanowiska pracy wraz z odpisem na zakładowy fundusz świadczeń socjalnych - ok. 40 tys. zł) ${ }^{31}$.

${ }^{29}$ Ustawa z dnia 19 sierpnia 2011 r. o zmianie ustawy o odpowiedzialności..., art. 13 oraz por. Uzasadnienie rządowego projektu...

${ }^{30}$ Ibidem, art. 13, 14.

${ }^{31}$ Ibidem, art. 17 oraz por. Uzasadnienie rządowego projektu... 
Podsumowując - w ogólnym ujęciu szacowana wysokość wydatków na funkcjonowanie komisji pierwszej instancji, według stanu prawnego obowiązującego przed wejściem w życie ustawy zmieniającej, wynosiłaby ok. 3770250 zł. Z kolei zmniejszenie liczby komisji orzekających oraz wprowadzenie zmian wskaźników ma skutkować obniżeniem tych wydatków do wysokości 2485789 zł i tym samym prowadzić do oszczędności ok. 1284460 zł. Zarówno z ekonomicznego, jak i praktycznego punktu widzenia dokonanie ograniczenia liczby komisji orzekających $-\mathrm{z}$ siedemnastu resortowych komisji orzekających do trzech międzyresortowych komisji orzekających - było zatem niezbędnym i słusznym rozwiązaniem. System odpowiedzialności za naruszenie dyscypliny finansów publicznych ma bowiem skutecznie służyć eliminowaniu niezgodnych $\mathrm{z}$ prawem zachowań $\mathrm{w}$ zakresie gospodarowania środkami publicznymi, zaś wszelkie rozwiązania prawne powinny wypływać z pragmatycznego ujęcia ich przydatności w dochodzeniu odpowiedzialności w przypadku stwierdzonych naruszeń dyscypliny finansów publicznych ${ }^{32}$.

\footnotetext{
${ }^{32}$ Por. Uzasadnienie rządowego projektu...
} 